\title{
EKLEZJALNE I NAUKOWE ZADANIE TEOLOGA W ŚWIETLE INSTRUKCJI DONUM VERITATIS KONGREGACJI NAUKI WIARY
}

\section{THE ECCLESIAL AND SCIENTIFIC TASK OF THE THEOLOGIAN IN THE LIGHT OF THE INSTRUCTION DONUM VERITATIS OF THE CONGREGATION FOR THE DOCTRINE OF THE FAITH}

In this article the instruction Donum veritatis on the vocation of the theologian in the Church, published by the Congregation for the Doctrine of Faith on 24th May 1990, is treated as the benchmark for the undertaken reflection on the ecclesial and scientific dimension of theology. This document still constitutes an abundant source of guidelines concerning theology and the way in which it should be pursued by each and every Catholic theologian. The instruction draws the attention primarily to a personal vocation of the theologian who remains in the service of the fellowship of God's People. It results from the very nature of the truth revealed by God which was mercifully conveyed to man so as to bring him to salvation. The gift of truth defines the nature of theology which is a scientific service to God's truth and by the same token also to God's People. One of the key elements of this service is the cooperation with the Magisterium of the Catholic Church while preserving its own autonomy. The principle of complementarity is a key factor in this respect and it also determines the ecclesial character of fulfilling the vocation of the theologian.

Key words: theology, faith, scholarship, ecclesiality, magisterium of the Catholic Church. 
Jednym z kluczowych zagadnień w ramach dzisiejszych poszukiwań dotyczących natury teologii jest równocześnie odpowiednie spojrzenie na postać teologa, przede wszystkim na jego misję eklezjalną, ale także na rozmaite niebezpieczeństwa, które mu zagrażają w owocnym pełnieniu tej misji. Bycie teologiem oznacza dzisiaj zajmowanie bardzo newralgicznego miejsca w życiu Kościoła, skoro na teologu spoczywa zadanie czuwania nad autentycznością wiary i misji duszpasterskiej Kościoła, a w związku z tym także pojawia się ryzyko rozminięcia się $z$ adekwatnym wypełnianiem tego zadania. Teolog nie posiada przywileju nieomylności; jego siłą jest prowadzony namysł krytyczny nad rzeczywistością wiary i jej faktycznego przeżywania przez wierzących, oczywiście, namysł oświecony przez wiarę, ale nie jest to jedyna siła, która decyduje o byciu teologiem ${ }^{1}$. Pojawia się wymóg uległości słowu Bożemu i posłuszeństwa oficjalnemu głosowi Kościoła, wierności żywej Tradycji, ducha służby i pokory, wrażliwości na znaki czasu, dialogu ze światem i inne. Biorąc pod uwagę te fakty, wydaje się rzeczą jak najbardziej uzasadnioną, podjęcie dalszego namysłu nad rolą teologa w Kościele i nad niektórymi aspektami jego pracy. W tym celu proponuję sięgnąć do ciągle niedocenianej instrukcji Donum veritatis o powołaniu teologa w Kościele, ogłoszonej przez Kongregację Nauki Wiary 24 maja 1990 roku², która wraz z upływem czasu jawi się jako dokument naznaczony duchem profetycznym. Ma ona ciągle wiele do powiedzenia w kwestiach dotyczących teologii w Kościele oraz sposobu jej uprawiania przez każdego teologa katolickiego.

\section{Powołanie teologa}

Czytając instrukcję Donum veritatis już w pierwszej chwili zauważamy, że nie tyle chodzi w niej o teologię, co raczej o samego teologa. Oczywiście, dokonanie rozdzielenia między teologią i teologiem jest bardzo trudne ze względu na specyfikę ujmowania teologii w Kościele, dlatego w niniejszym artykule będziemy mówić zarówno o teologii, jak i o teologu oraz o jego pracy teologicznej, uznając te pojęcia za właściwie równoważne. Taki sposób traktowania tych pojęć jest obecny także w instrukcji. Trzeba jednak uznać, że jest

$1 \quad$ Por. G. Cottier, Les chemins de la raison. Questions d'épistémologie, théologique et philosophique, Saint-Maur 1997, s. 71-92.

2 Por. Kongregacja Nauki Wiary, Instrukcja Donum veritatis (24 maja 1990), [w:] W trosce o petnię wiary. Dokumenty Kongregacji Nauki Wiary 1966-1994, (red.) J. Królikowski, Z. Zimowski, Tarnów 2010, s. 425-445. Por. także: Congregazione per la Dottrina della Fede, Istruzione „Donum veritatis” sulla vocazione ecclesiale del teologo. 24 maggio 1990, Città del Vaticano 1993 (Documenti e studi, 14); J. Ratzinger, Instrukcja O powołaniu teologa w Kościele, [w:] tenże, Wiara w Piśmie i Tradycji. Teologiczna nauka o zasadach, tłum. J. Merecki, Lublin 2018, s. 607-623 („Opera omnia”, IX/1). 
nowością bez precedensu, że Donum veritatis - jak podkreśla już sam tytuł mówi o „powołaniu teologa”. Oznacza to ukierunkowanie dyskursu na wnętrze osoby, czyli miejsce, w którym spotykają się ze sobą powołanie Boże i decyzja człowieka. Jest znaczące, że instrukcja na pierwszym miejscu sytuuje osobę, a nie jej pracę, mimo iż dopuszcza, że w dynamizmie komunii eklezjalnej wymiar osobowy teologa pokrywa się z jej wymiarem strukturalnym i instytucjonalnym. Teolog jest więc dogłębnie zanurzony w Kościół, zajmując w nim całkowicie szczególną pozycję. Jest ponadto interesujące, że dla instrukcji Donum veritatis powołanie teologa jest pierwszorzędnie osobową relacją z Bogiem i z Jego Kościołem. W oparciu o tę relację staje się ono służbą eklezjalną. Mamy tu odniesienie do klasycznej zasady, według której sposób bycia określa sposób działania (agere sequitur esse).

Przyjęte w Donum veritatis wewnętrzne założenie zwraca więc uwagę, że „służba” eklezjalna i naukowa teologa powinna być mocno usytuowana w ramach całościowej wizji Kościoła, tajemnicy komunii i misji. Zasługą instrukcji jest właśnie próba odczytania powołania teologa w ramach pełnej rzeczywistości Kościoła, to znaczy uwzględniając główne współrzędne wynikające $z$ jego natury i jego misji. Instrukcja ma przede wszystkim na względzie globalne rozumienie Kościoła jako podmiotu historycznego, którym jest nowy Lud Boży, a który „wywodzi się z jedności Ojca, Syna i Ducha Świętego, [...] jest tajemnicą komunii, z woli swojego Założyciela zorganizowanej wokól hierarchii" (nr 39). W tym samym kontekście instrukcja ukazuje naturę Kościoła, odwołując się do innej kategorii soborowej, a mianowicie do kategorii sakramentu: „Kościół jest «niejako sakramentem, czyli znakiem i narzędziem wewnętrznego zjednoczenia z Bogiem i jedności całego rodzaju ludzkiego»" (nr 40). Nawiązuje ona również do kategorii Kościoła jako „Ciała Chrystusa”, w którego budowaniu uczestniczą teologowie ze swoim własnym charyzmatem (nr 40). Wychodząc zatem od całościowej wizji Kościoła - opisanego czterema najczęściej powracającymi w eklezjologii posoborowej kategoriami, to znaczy ludu Bożego, komunii, sakramentu i Ciała Chrystusa - oraz sytuując zarówno Urząd Nauczycielski Kościoła, jak i teologię w ramach tej wspólnoty wierzących, instrukcja Donum veritatis może stwierdzić, że mamy tutaj do czynienia z „dwoma witalnymi funkcjami Kościoła, które dla dobra ludu Bożego powinny się wzajemnie przenikać i wzbogacać” (nr 40).

Wydaje się, że troska, która została wyrażona w instrukcji nie dotyczy tylko ortodoksji teologii czy ochrony komunii eklezjalnej, co jest oczywiście niezwykle ważną sprawą i może zarazem prowadzić do napięć czy konfliktów między wspomnianymi dwoma funkcjami, ale także dotyczy misji Kościoła i jej owocnego wypełniania w świecie. W globalnej wizji Kościoła nie może nie wyłonić się wewnętrzna więź między wszystkimi jego funkcjami oraz misją, którą jest 
wezwany pełnić między ludźmi. Wszelka refleksja teologiczna nad istnieniem i aktywnością Urzędu Nauczycielskiego i teologii w Kościele musi uwzględniać także jego misję zbawczą, skoro jego skuteczność w spełnianiu funkcji ewangelizacyjnej jest zawsze pierwszorzędnym kryterium w rozeznawaniu autentyczności każdej funkcji i charyzmatu oraz stanu wypełniania zleconego zadania teoretycznego i praktycznego w życiu eklezjalnym.

Instrukcja Donum veritatis odnosi się bezpośrednio do teologii „katolickiej” i do teologów „katolickich”, chociaż wiele jej wypowiedzi można uznać za odnoszące się także do teologów innych Kościołów i wspólnot chrześcijańskich. Stosując 40 razy pojęcie "teolog” bez przymiotników, instrukcja tylko jeden raz mówi o teologu „katolickim” (nr 38), gdy wskazuje na „prawe sumienie”, które „zakłada wiarę w słowo Boże, którego bogactwo ma on zgłębiać, ale także miłość do Kościoła, w którym pełni on swoją misję oraz szacunek dla Urzędu Nauczycielskiego, wspieranego opieką Bożą" (nr 38). Nie ulega wątpliwości, że opisując „powołanie teologa w Kościele”, instrukcja uwzględnia przede wszystkim „teologa katolickiego” oraz status epistemologiczny „teologii katolickiej”, co można wywnioskować z niektórych wypowiedzi.

a) Instrukcja Donum veritatis traktuje zawsze teologa w ramach ludu Bożego; jest on wezwany do spełniania swojej funkcji „pod kierownictwem Urzędu Nauczycielskiego” i „z Urzędem Nauczycielskim” (nr 13 i 21). Chodzi więc o cum i sub, które mają kluczowe znaczenie w określeniu i kształtowaniu wzajemnych relacji, ale są one też trudne do jednoznacznego uzgodnienia między sobą, ponieważ chodzi o rzeczywistości dynamiczne i uwarunkowane historycznie. W każdym jednak razie chodzi o „coraz głębsze zrozumienie słowa Bożego zawartego w natchnionym Piśmie Świętym i przekazanego przez żywą Tradycję Kościoła" (nr 6). Teolog, o którym mówi instrukcja w cytowanej wypowiedzi zostaje więc usytuowany w ramach statusu epistemologicznego „teologii katolickiej”.

b) Ponieważ pozostaje zawsze związany z Kościołem, którego wiarę wyznaje i którego jest członkiem, w rozwijaniu w ramach wspólnoty eklezjalnej swojej funkcji poszukiwania „rozumienia wiary” (nr 22), teolog katolicki jest zobowiązany do wspólpracy z Urzędem Nauczycielskim nie tylko z powodu wymogów wynikających ze statusu epistemologicznego teologii katolickiej, ale także z racji „zobowiązania, jakie teolog podejmuje, przyjmując swój urząd" (nr 22). Teolog podejmuje swoje powołanie świadomie i dobrowolnie, dlatego spoczywa na nim odpowiedzialność za jego owocne wypełnienie, zarówno z punktu widzenia osobistego, jak i eklezjalnego. Nie jest to jednak powołanie prywatne, ale posiada wewnętrzny charakter eklezjalny, co oznacza także pierwszeństwo dawane temu, co eklezjalne. 


\section{Zadanie teologa}

Wiara jest pierwszorzędną rzeczywistością w życiu chrześcijańskim, gdyż stanowi jego fundament oraz jego cel. Z tej samej racji ma ona charakter determinujący dla teologii. W antropologii teologicznej słusznie mówi się o otwartości i gotowości człowieka na słuchanie i przyjęcie słowa, które jest skierowane do niego z zewnątrz - od Boga ${ }^{3}$. Człowiek jest zdolny przyjąć słowo Boże - „dar prawdy”, ponieważ został stworzony na obraz Boga i dzieli z Nim pewną współnaturalność zarówno w porządku bytu, jak i w porząadku działania. Założenie antropologiczne i wydarzenie historyczne są dwoma danymi, które ściśle łączą się ze sobą i przenikają wzajemnie, a tym samym poprzedzają każdy dyskurs na temat teologii.

Kwestię specyfiki teologii można podjąć w sposób adekwatny jedynie w ramach szerszej refleksji, która status epistemologiczny teologii opiera na jej rozumieniu jako scientia fidei. Przejście od teologii do teologa nie jest rozumiane w sensie alternatywnym, które zakładałoby przeniesienie postaci teologa na drugi plan, gdyż w Donum veritatis jest oczywista intencja uwypuklenia funkcji teologa w Kościele, która w niczym nie powoduje pomniejszenia nauczania teologii w sensie akademickim, czyli naukowym ${ }^{4}$.

a) Funkcja teologa (i teologii) została przedstawiona w instrukcji Donum veritatis $\mathrm{w}$ połączeniu zarówno z przedmiotem teologii, którym jest Objawienie Boże, czyli „dar prawdy” dany przez Boga, urzeczywistniony przez Syna Bożego i aktualizowany przez Ducha Świętego (nr. 1-2), jak i z wiarą jako odpowiedzią na powołanie Boże. Instrukcja ujmuje adekwatnie te dwa elementy, stanowiące punkt wyjścia teologii, gdy ją opisuje jako „poznanie rozumowe” (nr 12).

b) Wiara chrześcijańska jest odpowiedzią człowieka na „prawdę przekazaną w Objawieniu Bożym" (nr 1). Punktem wyjścia jest dar objawienia. Człowiek przyjmuje słowo Boże i nim żyje, opiera się na nim i ciągle stara się rozwijać duchowo na jego fundamencie. Pojęcie „wiary”, które wchodzi w definicję teologii, wskazuje, że wychodzi ona od wiary, zakłada ją i jest przez nią wymagana. Pierwszym elementem teologii jest więc wiara, nie tylko stanowiąc jej punkt wyjścia, ale także stałą postawę osobową w teologu, przenikającą jego pracę teologiczną. Traktując wiarę jako dar i odpowiedź, wyłaniają się ponadto dwa główne aspekty aktu wiary, to

3 Idea Karla Rahnera, według którego człowiek jest „słuchaczem Słowa” ma nam na pewno wiele do powiedzenia w antropologii teologicznej. Por. K. Rahner, Stuchacz Stowa, tłum. R. Samek, Kęty 2008.

4 Por. A. Staglianò, La teologia "che serve". Sul compito scientifico-ecclesiale del teologo per la nuova evangelizzazione, Torino 1996. 
znaczy aspekt subiektywny i aspekt obiektywny. Wiara w swoim właściwym wyrazie jest zasadniczo fides qua, czyli osobistą opcją egzystencjalną, oraz fides quae, czyli obiektywną treścią doktrynalną kształtującą tę opcję osobistą̧. Pojęcie wiary musi więc wejść do definicji teologii; co więcej, można uzasadnić, że poprawne rozumienie teologii zależy od właściwego rozumienia wiary, tak jak prawomocność teologii, to znaczy jej charakter eklezjalny, a zarazem naukowy, przybiera decydujący kształt w relacji do prawomocności wiary.

c) Wymiar badawczy teologii (quaerens) - zgodnie z rozumieniem wiary zaprezentowanym przez św. Anzelma z Canterbury - w odniesieniu do wiary wynika $z$ tego, że zadaje ona pytania o siebie samą i szuka odpowiedniego samorozumeinia. Jest to poszukiwanie o charakterze krytycznym, czyli jest podejmowane z pełną świadomością istniejących obiektywnych „podstaw” wiary. Wynika z tego także status epistemologiczny teologii. Chodzi ponadto o poszukiwanie prowadzone w sposób metodyczny, to znaczy odpowiednio do zasad określonych przez jej przedmiot i przez jej charakter jako refleksji wiary. Jest ona także pracą systematyczną, nastawioną na spójne pogłębienie treści objawienia w ich wzajemnych relacjach (nexus mysteriorum) oraz odniesienia tych treści do centrum wiary, którym jest Jezus Chrystus, aby uczynić je widocznym w świecie. W końcu, teologia jest otwarta w sposób nieograniczony na dalsze badania, ponieważ jej przedmiot, już posiadany przez wiarę, jest jednak w sobie nieskończony, a tym samym także niewyczerpalny. Papież św. Paweł VI wyraził bardzo znamiennie tę dialektykę wiary w relacji do jej przedmiotu: „[Wiara] jest najpierw posiadaniem: człowiek wierzący posiada już kilka najważniejszych prawd wywodzących się ze słowa Bożego. Jest już strażnikiem kilku prawd objawionych, które go zagarnęły i władają nim. Korzysta już z kilku pewników, dających jego umysłowi pełnię i siłę, zarazem pragnienie wyrażania ich ze czcią, bo ożywia jego życie wewnętrzne. [...] Lecz musimy zdawać sobie sprawę $z$ tego, że to posiadanie wiary nie tylko nie wyklucza dalszych poszukiwań, lecz się ich domaga. Nasze posiadanie Boga w tym życiu nie jest nigdy całkowite. Jest dopiero wstępem, pierwszą iskrą, zapraszającą do zdobycia światła"•. Wynika $z$ tego, że na teologu spoczywa zadanie prowadzenia badań, które mają wymiary nieskończone. Oznacza to zarazem konieczność, należącą do samego doświadczenia i samej wędrówki wiary, ciągle nowych przemyśleń,

5 Por. R. Fisichella, Ecclesialità dell'atto di fede, [w:] Noi crediamo. Per una teologia dell'atto di fede, (red.) R. Fisichella, Roma 1993, s. 59-97.

6 Paweł VI, Wiara w Boga i człowiek (audiencja ogólna, 10 lipca 1968), [w:] tenże, Trwajcie mocni w wierze, (red.) J. Ozóg, Kraków 1974, s. 70-71. 
szukania jasności, otwierania się coraz bardziej na tajemnicę Boga, a zarazem na pokazywanie jej znaczenia w ramach dziejów, w które wchodzi i w których żyje i działa.

Jeśli chodzi o status epistemologiczny teologii, instrukcja Donum veritatis jest bardzo jasna w swoim przesłaniu. Dając opisowe pojęcie teologii, stwierdza: „Teologia [...] przez refleksję dochodzi do coraz głębszego zrozumienia słowa Bożego, zawartego w Piśmie Świętym i wiernie przekazywanego przez żywą Tradycję Kościoła pod przewodnictwem Urzędu Nauczycielskiego; stara się ona wyjaśnić naukę zawartą w objawieniu zgodnie $z$ wymaganiami rozumu oraz nadaje mu jednorodną i systematyczną formę" (nr 21).

Przywołana wypowiedź zarysowuje status epistemologiczny uprawiania teologii, który sytuuje się między eklezjalnością i naukowością. Teologia otrzymuje swój przedmiot od Boga, który udziela się człowiekowi w słowach i w wydarzeniach (verbis gestisque). Zawsze słucha ona słowa Bożego zawartego w Piśmie Świętym i przekazywanego przez żywą Tradycję, która obejmuje także Urząd Nauczycielski Kościoła z jego specyficzną misją. Urząd Nauczycielski Kościoła i teologia są więc różnymi funkcjami, ale łączą się one ze sobą w służbie na rzecz objawienia i wiary eklezjalnej. Zadaniem teologii jest wyjaśnianie objawienia Bożego w relacji do „instancji rozumu”, czyli w odniesieniu do pytań stawianych przez człowieka.

Można więc powiedzieć, że teologia jest „wiarą krytyczną”, a więc nie jest po prostu wiarą, ale jej specjalnym określeniem i ukierunkowaniem. Można zaproponować różne modele ujęcia relacji „wiara-rozum” i można ją wyrażać w różny sposób. Instrukcja Donum veritatis nie zajmuje się wprost tym zagadnieniem, zadowalając się stwierdzeniem, że prawda objawiona „nie jest [...] sprzeczna z ludzkim rozumem” (nr 1), a w innym miejscu dodając: „Chociaż prawda objawiona przekracza rozum ludzki, to jednak pozostaje z nim w głębokiej harmonii" (nr 10). Te dwa charakterystyczne stwierdzenia, bardzo tradycyjne, są ze sobą nierozdzielnie powiązane i na siebie twórczo oddziałują w przypadku podejmowania otwartych interpretacji. Za niektórymi dzisiejszymi postawami, które usiłują wziąć wiarę niejako „w nawias” jako uprzedni warunek uprawiania teologii (czyli badania krytycznego), zauważamy jednak odradzanie się starego przesądu widzącego wiarę i wiedzę krytyczną w kluczu alternatywnym (albo-albo), ale ,jest to tylko przesąd, który nie wytrzymuje krytyki. Wiara nie zastępuje badania krytycznego ani o nim nie przesądza, ale w swojej perspektywie je przedłuża i pogłębia"?

Istnieje jeszcze bardziej lub mniej ukryte przeciwstawienie między wiarą i poznaniem (rozumem), które fatalnie eliminuje albo wiarę, albo poznanie,

$7 \quad$ G. Colombo, Professione «teologo», Milano 1996, s. 32. 
gdy tymczasem potrzebują się one nawzajem. Kardynał Joseph Ratzinger tak pisał na ten temat: „Rozum ludzki nie jest [...] wcale autonomiczny. Jego środowiskiem są zależności historyczne, które (jak widzimy) zniekształcają jego perspektywę. Dlatego potrzebuje on też pomocy ze strony historii, aby wznieść się ponad bariery historyczne. Uważam, że neoscholastyczny racjonalizm spalif na panewce. Chciał on bowiem z czysto racjonalną pewnością, zupełnie niezależną od wiary, dokonać rekonstrukcji Preambula Fidei. Wszystkie próby zmierzające do tego muszą skończyć się niepowodzeniem. [...] Bynajmniej nie poślednią funkcją wiary jest to, że oferuje ona zbawienie rozumowi jako rozumowi, nie pogwałca jego praw, nie zostawia na zewnątrz, lecz przywraca samemu sobie. [...] Rozum nie może być zdrowy bez udziału wiary, lecz wiara bez rozumu nie będzie ludzka" ${ }^{8}$. W encyklice Fides et ratio Papież Jan Paweł II w tym samym duchu słusznie pisał o „dramacie rozdziału między wiarą a rozumem”; stwierdza w niej m.in.: „Obecna relacja między wiarą a rozumem domaga się wysiłku wnikliwego rozeznania, ponieważ zarówno rozum, jak i wiara zostały zubożone i osłabione w swych wzajemnych odniesieniach. Rozum, pozbawiony wsparcia ze strony Objawienia, podążał bocznymi drogami, na których istniało ryzyko zagubienia jego ostatecznego celu. Wiara, pozbawiona oparcia w rozumie, skupiła się bardziej na uczuciach i przeżyciach, co stwarza zagrożenie, że przestanie być propozycją uniwersalną. Złudne jest mniemanie, że wiara może silniej oddziaływać na słaby rozum; przeciwnie, jest wówczas narażona na poważne niebezpieczeństwo, może bowiem zostać sprowadzona do poziomu mitu lub przesądu. Analogicznie, gdy rozum nie ma do czynienia z dojrzałą wiarą, brakuje mu bodźca, który kazałby skupić uwagę na specyfice i głębi bytu" (nr 48).

\section{Urząd Nauczycielski Kościoła i teologia w służbie daru prawdy}

Dar prawdy został powierzony przez Boga jego ludowi i jest przez niego przekazywany. Nie dzieje się to jednak automatycznie, ale opiera się na zaangażowaniu Urzędu Nauczycielskiego Kościoła i teologów9.

a) Instrukcja Donum veritatis w swoim wykładzie opiera się na eklezjologii zawartej w nauczaniu II Soboru Watykańskiego, zwłaszcza w konstytucjach Lumen gentium i Dei Verbum. Punktem wyjścia jest rozumienie

\footnotetext{
$8 \quad$ J. Ratzinger, Wiara - prawda - tolerancja. Chrześcijaństwo a religie świata, tłum. R. Zajączkowski, Kielce 2004, s. 109-110.

9 Na temat relacji między Urzędem Nauczycielskim Kościoła i teologią por. Międzynarodowa Komisja Teologiczna, Urząd Nauczycielski Kościota i teologia (1976), [w:] Od wiary do teologii. Dokumenty Międzynarodowej Komisji Teologicznej 1969-1996, (red.) J. Królikowski, Kraków 2000, s. 55-69.
} 
Kościoła jako podmiotu historycznego, budowanego i kształtowanego przez słowo Boże (Ecclesia - creatura Verbi), dane ludowi Bożemu (nr. 3-5); dopiero na drugim miejscu jest mowa o teologii i Urzędzie Nauczycielskim Kościoła jako charyzmatach czy też funkcjach eklezjalnych w służbie zgromadzenia wiernych (congregatio fidelium). Nierozdzielny związek zachodzący między Objawieniem Bożym (słowa i wydarzenia) i wspólnotą wierzącą jest kluczowym elementem współczesnej eklezjologii. Relacja „słowo-wspólnota wiary” jest źródłem obydwu rzeczywistości oraz uwzględnia pewne pierwszeństwo słowa w stosunku do Kościoła. Nie chodzi jednak o pierwszeństwo chronologiczne, ale przede wszystkim o pierwszeństwo w porządku ontologicznym i logicznym, które wyraża się w eklezjologii stwierdzeniem, że Kościól jest pierwszorzędnym podmiotem, czyli adresatem Objawienia Bożego. Prawdy wiary nie zostały powierzone wyizolowanej jednostce. Bóg zechciał tworzyć dzieje Zbawienia przy udziale podmiotu historycznego, którym jest Jego lud - Kościół. Kościołowi jest więc powierzona misja wiernego przekazywania tej prawdy wszystkim narodom, aż do chwalebnego powrotu Pana. Na dar, czyli powołanie Boże - stwierdza Donum veritatis - lud Boży odpowiada „przede wszystkim przez życie wiary i miłości” (nr 4).

b) W obydwu wspomnianych konstytucjach II Sobór Watykański wyszedł od elementów wspólnych wszystkim członkom wspólnoty wierzących; wybór ten kontynuuje także instrukcja Donum veritatis. Sobór zamierzał wprowadzić równowagę w poszczególne postawy częściowe w przypisaniu odpowiedzialności Kościołowi wobec słowa objawionego. Taka odpowiedzialność spoczywa na całej wspólnocie wierzącej, na wszystkich kategoriach osób, które ją tworzą. Donum veritatis przypomina kilka ważnych pryncypiów:

- Prawda jest darem Boga dla Jego ludu, nie tylko dla pasterzy czy dla teologów;

- na całym ludzie Bożym, z różnymi obecnymi w nim powołaniami i charyzmatami, spoczywa misja przekazywania Prawdy;

- całość wiernych jest - w pewnych okolicznościach - wolna od braku w wierze.

Uznając pierwszeństwo wspólnoty wierzących wobec specyficznej funkcji pasterzy, nauczanie Kościoła stara się uniknąć wszelkich tendencji, pośrednich lub bezpośrednich, których rezultatem byłoby zbytnie podkreślanie funkcji Urzędu Nauczycielskiego Kościoła lub sytuowanie go poza lub ponad wspólnotą wierzącą. W odniesieniu do tej kwestii, Donum veritatis stwierdza: „Funkcja Urzędu Nauczycielskiego nie jest czymś zewnętrznym w stosunku do chrześcijańskiej prawdy ani czymś nałożonym na wiarę" (nr 14). 
Inna postawa, która mogłaby się pojawić, chociaż w innej mierze, polegałaby na wyeliminowaniu specyficznej funkcji Urzędu Nauczycielskiego na rzecz jednostronnego pierwszeństwa danego pisanemu słowu Bożemu, rozumianemu jako jedyne kryterium prawdy i prawości życia chrześcijańskiego we wspólnocie wierzących i zrównania wszystkich kategorii osób w Kościele.

II Sobór Watykański na pewno odczuwał w sposób żywy teologiczny wymóg przemyślenia integralnie transcendencji słowa Bożego i jest to jedno z jego największych osiągnięć. Konstytucja Dei Verbum stwierdza więc, że Urząd Nauczycielski nie jest ponad słowem Bożym, ale mu służy (ministrat), nauczając wiernie orędzia chrześcijańskiego: „Z nakazu Bożego i przy pomocy Ducha Świętego pobożnie słucha on słowa Bożego, święcie strzeże i wiernie wykłada" (nr 10).

Jeśli chodzi o teologię, określa ona samą siebie jako naukę o słowie Bożym. W odniesieniu do słowa Bożego, teologowie spełniają funkcję komplementarną w stosunku do Urzędu Nauczycielskiego Kościoła. Ich zadaniem jest poszukiwanie głębszego rozumienia słowa Bożego. Oznacza to m.in., że na teologach spoczywa zadanie nie tylko systematycznego opracowania i wykładu otrzymanej wiary, ale także jej nowe sformułowanie w kategoriach znaczących dla nowych sytuacji społeczno-kulturowych, a przede wszystkim badanie nowych dróg dostępu do tajemnicy słowa objawionego i poszukiwania jego mocy oddziaływania. Chodzi o refleksję naukową nad słowem Bożym, która nie ogranicza się tylko do strzeżenia otrzymanego skarbu, ale stara się także o to, aby nadać wierze takie wyrażenie, aby zbliżało do jej przyjęcia i życia nią, a będzie ono możliwe, jeśli uwzględni się sposób myślenia i mówienia naszego czasu. Kardynał Joseph Ratzinger zwracał uwagę na to zagadnienie w sposób bardzo przejrzysty: „Wiara chce wyprowadzić z tego, co dotychczasowe, i prowadzić do nowego poznania. Ponieważ ukazuje prawdy i fakty, dlatego nie jest tylko troską o tradycję w pewnym ograniczonym kręgu. Od początku istnieje jako uznanie faktów i prawd, które zmuszają swoich pierwszych wyznawców do wyjścia poza swoją dotychczasową przestrzeń i do wzywania innych do nowej wspólnoty. Dlatego teologia jest zjawiskiem swoiście chrześcijańskim" ${ }^{10}$.

Podczas gdy uznaje się jako oczywiste, że Urząd Nauczycielski spełnia swoją funkcję w ramach wspólnoty wierzących, jest nie mniej pewna teza, że funkcja teologów spełnia się w Kościele, ponieważ „wiarą, w ramach której rozwija się funkcja krytyczna, jest właśnie wiara Kościoła. Dlatego «zmysł Kościoła» jest «wewnętrznym kryterium» uprawiania teologii, nie na mocy nacisku prawnego, ale na mocy konieczności logicznej” ${ }^{11}$. Jest nie do pomyślenia teologia

10 J. Ratzinger, Kościót i teologia naukowa, [w:] tenże, Wiara w Piśmie i Tradycji, s. 601-602.

11 G. Colombo, Professione «teologo», s. 33. 
„zewnętrzna” w stosunku do wiary wspólnoty wierzących. „Pod tym względem należy sprecyzować, że wiara i poszukiwanie (w sensie poszukiwania krytycznego) są nieodłączne od siebie, a więc nie mogą być usytuowane paralelnie" ${ }^{2}$. Teologia domaga się wewnętrznego i coraz dojrzalszego egzystencjalnie uczestniczenia w życiu wspólnoty kościelnej.

\section{Komplementarność Urzędu Nauczycielskiego i teologii}

Urząd Nauczycielski Kościoła i teologia w najwyższym stopniu spełniają właściwe dla siebie funkcje, gdy dokonują rozeznania dotyczącego zmysłu wiary (sensus fidei) wspólnoty wierzących ${ }^{13}$.

a) Wśród fundamentów teologicznych komplementarności funkcji Urzędu Nauczycielskiego i teologii trzeba zwrócić uwagę na ich związek wewnętrzny z sensus fidei wierzących (nr. 4, 8, 13), stanowiący verus locus theologicus, w którym słowo Boże jest zawarte. W świetle zasad sformułowanych przez św. Wincentego z Lerynu w Commonitorium: id teneamus quo ubique (uniwersalism), quo semper (starożytność), quod ad omnibus creditum est (powszechna zgodność) - ma ono gwarancję wolności od braku.

Instrukcja Donum veritatis w swoim wykładzie opiera się na konstytucji soborowej Lumen gentium, która ukazuje funkcję profetyczną wspólnoty wierzących spełnianą w świecie (nr. 4-5), zarówno wypowiadając się na temat powołania teologa, powołanego do intensyfikowania swojego życia wiary (łącząc badania naukowe i modlitwę), aby w ten sposób osiągnąć „większą wrażliwość na «nadprzyrodzony zmysł wiary», od którego wszystko zależy i w którym znajdzie niezawodną regułę kierującą jego refleksją oraz kryterium oceny poprawności jej wyników" (nr 8), jak również w traktowaniu zadania Urzędu Nauczycielskiego w ramach ludu Bożego, który - dzięki „nadprzyrodzonemu zmysłowi wiary” - jest wolny od błędu w swojej wierze „pod kierownictwem Urzędu Nauczycielskiego” (nr 13).

b) Zarówno pasterze, jak i teologowie spełniają odpowiednio właściwe dla siebie funkcje, pozostając wewnętrznie powiązani z autentycznym zmysłem wiary całości wierzących. Teologia jako nauka wiary musi odnosić się

12 Tamże.

13 Na temat rozwoju idei sensus fidei por. D. Vitali, Sensus fidelium. Una funzione ecclesiale di intelligenza della fede, Brescia 1993; D. J. Finucane, Sensus fidelium. The use of a concept in the post-Vatican II era, San Francisco-Bethesda-London 1996; Ch. Ohly, Sensus fidei fidelium. Zur Einordnung des Glaubenssinnes aller Gläubigen in die Communio-Struktur der Kirche im geschichtlichen Spiegel dogmatisch-kanonistischer Erkenntnisse und der Aussagen des II. Vaticanum, St. Ottilien 1999. 
do tego szczególnego poznania posiadanego przez wiernych z szacunkiem i otwartością duchową. Można powiedzieć, że z punktu widzenia badań naukowych teologia musi dowartościować, głębiej poznać i zrozumieć żywe i ożywiające więzy z głosem Tradycji Kościoła, który konkretyzuje się nie tylko w nauczaniu Urzędu Nauczycielskiego, w myśli ojców i doktorów, czy w liturgii, ale także w konkretnej wierności wyrażanej przez sensus fidei prostych wiernych.

Jest to zagadnienie, które $z$ punktu widzenia gnozeologii teologicznej znalazło dowartościowanie w dokumencie Międzynarodowej Komisji Teologicznej Teologia dzisiaj. Perspektywy, zasady i kryteria (nr. 33-36), w którym stwierdza się jednoznacznie: „Uwzględnienie sensus fidelium jest jednym z kryteriów teologii katolickiej" (nr 36) ${ }^{14}$. Oczywiście, wypowiedzi zawarte w tym dokumencie domagają się dalszych, wnikliwych analiz teologicznych. Mimo iż nie mamy do dyspozycji precyzyjnych formuł lub jednoznacznych ujęć teologicznych w tej materii, możemy jednak wyprowadzić kilka ogólnych, ale pewnych uwag eklezjologicznych na temat relacji między sensus fidei wierzących, funkcjami Urzędu Nauczycielskiego i teologią w Kościele.

c) W wypełnianiu swoich funkcji zarówno Urząd Nauczycielski, jak i teologia, zakładają wiarę Kościoła, z którą się wewnętrznie łączą i której są wyrazem. To stwierdzenie zakłada jednak zarazem zdystansowanie się w stosunku do każdego dążenia przypisującego absolutny charakter wspólnemu odczuwaniu w wierze ze strony całości wierzących, jakby to była po prostu jakaś postać najwyższego kryterium, mającego własne, autonomiczne znaczenie w stosunku do Urzędu Nauczycielskiego. Pod pewnymi względami jest możliwe mówienie o pierwszeństwie należącym do zmysłu wiary wierzących w stosunku do Urzędu Nauczycielskiego i do teologii, ale powinno być ono rozumiane jako zgodność w wierze ze strony całości wierzących, która obejmuje także pasterzy i teologów. Nie można nadać temu zmysłowi ani charakteru prawnego ani wartości absolutnej, czego konsekwencją byłoby sprowadzenie funkcji Urzędu Nauczycielskiego do jakiegoś zewnętrznego opisywania wspólnego odczuwania wiary i ogólnego ukierunkowywania wiary ludu chrześcijańskiego, aby potem przekazywać rezultaty tego opisu w sposób oficjalny, jakby stwierdzając, że wiara wspólnoty wskazuje hierarchię wartości, granice i kompetencje Urzędu Nauczycielskiego, bądź też określa warunki, aby jego wypowiedzi mogły zyskać przyjęcie.

14 Por. Międzynarodowa Komisja Teologiczna, Teologia dzisiaj. Perspektywy, zasady i kryteria, tłum. K. Stopa, Kraków 2012. 
d) We wzajemnym, strukturalnym przenikaniu się Urzędu Nauczycielskiego, teologów i wiernych manifestuje się także dynamizm komunijny wiary zachodzący między Urzędem Nauczycielskim i wspólnotą. Dlatego formuła ex fide - in fidem jest kluczowa zarówno z punktu widzenia strukturalnego, jak i operatywnego, w odniesieniu do korelacji między Urzędem Nauczycielskim i wspólnotą wiary. Wskazuje ona przede wszystkim na potrzebę stymulowania tego, co służy wzmocnieniu komunii między dwoma instancjami wiary.

Teologia powinna zwrócić większą uwagę na refleksję nad „aktualną” wiarą Kościoła, od niej wychodząc w swoich badaniach, skoro jest oczywisty jej wewnętrzny związek z wiarą Kościoła. Co więcej, teologia jest zrozumiała jako „moment dojrzewania” tej wiary i - biorąc pod uwagę jej charakter naukowy - jest jej elementem „koniecznym”. Można więc zasadnie stwierdzić, że zarówno teologia należy do Kościoła, jak również Kościół należy do teologii. Ta swoista „wewnętrzna wymienność”, wynikająca ze struktury objawienia, zakłada „interlokutora”, człowieka lub wspólnotę, który przyjmuje wiarę w sposób odpowiedzialny.

Między wiarą Kościoła i teologią zachodzi więc wewnętrzny i głęboki związek. Wiara jest witalnym i trwałym źródłem teologii, która rodzi się z zadawania pytań i szukania odpowiedzi w Objawieniu Bożym, zachowując w tym procesie intelektualnym wolną i osobową więź z Chrystusem oraz pełną gotowość kierowania się Objawieniem Bożym. Krytyczne rozumienie wiary sytuuje się więc $\mathrm{w}$ jej ramach, ponieważ przedmiot jest dawany teologii w samym akcie wiary. Ukazana tutaj relacja między teologią i wiarą, której ostatecznym źródłem jest przyjęcie przedmiotu od wiary, wskazuje na eklezjalność teologii, to znaczy jej związek z Kościołem jako wspólnotą wiary i Urzędem Nauczycielskim.

\section{Zakończenie}

„Kościół życzy sobie samodzielnych badań teologicznych, oddzielonych od kościelnego Urzędu Nauczycielskiego, ale uznających jego nadrzędność we wspólnej służbie prawdzie wiary i Ludowi Bożemu" - takie życzenie wyraził Papież św. Jan Paweł II w czasie spotkania z profesorami i studentami Republiki Federalnej Niemiec 15 listopada 1980 roku ${ }^{15}$. Właściwie biorąc, możemy powiedzieć, że takie właśnie jest główne, przedstawione w formie systematycznej, przesłanie instrukcji Donum veritatis o powołaniu teologa w Kościele. Podkreśla ona racjonalność wiary, której konkretnym wyrażeniem jest teologia

15 Jan Paweł II, Nauka - teologia - Magisterium. Spotkanie z profesorami i studentami Republiki Federalnej Niemiec, Kolonia, 15 listopada 1980, [w:] Uniwersytety w nauczaniu Jana Pawta II, t. 1 (1978-1988), wstęp M. Piwko, wprow. S. Urbański, Warszawa 1999, s. 209. 
jako nauka wiary. Naukowość, która odzwierciedla praktycznie uznanie racjonalności, pozostaje w ten sposób włączona po raz kolejny w tajemnicę wiary chrześcijańskiej. Niejako drugim biegunem wiary i teologii jest jej eklezjalność. Nie ma prywatnej wiary i nie ma prywatnej teologii. Autentyczna jest tylko taka teologia, która nosi na sobie wyraźną eklezjalność, z niej wyrasta i do niej prowadzi. Powołaniem teologa jest zatem uprawianie takiej teologii, która rozwija się między dwoma biegunami: eklezjalnością i naukowością.

Słowa kluczowe: teologia, wiara, naukowość, eklezjalność, Urząd Nauczycielski Kościoła.

\section{Bibliografia:}

1. Colombo G., Professione «teologo», Milano 1996.

2. Congregazione per la Dottrina della Fede, Istruzione „Donum veritatis” sulla vocazione ecclesiale del teologo. 24 maggio 1990, Città del Vaticano 1993 (Documenti e studi, 14).

3. Cottier G., Les chemins de la raison. Questions d'épistémologie, théologique et philosophique, Saint-Maur 1997.

4. Finucane D. J., Sensus fidelium. The use of a concept in the post-Vatican II era, San Francisco-Bethesda-London 1996.

5. Fisichella R., Ecclesialità dell'atto di fede, [w:] Noi crediamo. Per una teologia dell'atto di fede, (red.) R. Fisichella, Roma 1993, s. 59-97.

6. Kongregacja Nauki Wiary, Instrukcja Donum veritatis (24 maja 1990 r.), [w:] W trosce o petnię wiary. Dokumenty Kongregacji Nauki Wiary 1966-1994, (red.) J. Królikowski, Z. Zimowski, Tarnów 2010, s. 425-445.

7. Międzynarodowa Komisja Teologiczna, Urzad Nauczycielski Kościoła i teologia (1976), [w:] Od wiary do teologii. Dokumenty Międzynarodowej Komisji Teologicznej 1969-1996, (red.) J. Królikowski, Kraków 2000, s. 55-69.

8. Międzynarodowa Komisja Teologiczna, Teologia dzisiaj. Perspektywy, zasady i kryteria, tłum. K. Stopa, Kraków 2012.

9. Ohly Ch., Sensus fidei fidelium. Zur Einordnung des Glaubenssinnes aller Gläubigen in die Communio-Struktur der Kirche im geschichtlichen Spiegel dogmatisch-kanonistischer Erkenntnisse und der Aussagen des II. Vaticanum, St. Ottilien 1999.

10. Paweł VI, Trwajcie mocni w wierze, (red.) J. Oźóg, Kraków 1974

11. Rahner K., Stuchacz Stowa, tłum. R. Samek, Kęty 2008.

12. Ratzinger J., Wiara - prawda - tolerancja. Chrześcijanstwo a religie świata, thum. R. Zajączkowski, Kielce 2004.

13. Ratzinger J., Wiara w Piśmie $i$ Tradycji. Teologiczna nauka o zasadach, thum. J. Merecki, Lublin 2018 (Opera omnia, IX/1).

14. Staglianò A., La teologia "che serve". Sul compito scientifico-ecclesiale del teologo per la nuova evangelizzazione, Torino 1996.

15. Vitali D., Sensus fidelium. Una funzione ecclesiale di intelligenza della fede, Brescia 1993. 